\title{
Enhanced dopamine availability and response readiness. The influence of 3 doses of methylphenidate on contingent negative variation in the EEG of healthy volunteers
}

Citation for published version (APA):

Linssen, A. M. W., Vuurman, E. F. P. M., Sambeth, A., Navé, S., \& Riedel, W. J. (2011). Enhanced dopamine availability and response readiness. The influence of 3 doses of methylphenidate on contingent negative variation in the EEG of healthy volunteers. Neuroscience Letters, 500(suppl.), [e25]. https://doi.org/10.1016/j.neulet.2011.05.138

Document status and date:

Published: 01/01/2011

DOI:

10.1016/j.neulet.2011.05.138

Document Version:

Publisher's PDF, also known as Version of record

\section{Document license:}

Taverne

\section{Please check the document version of this publication:}

- A submitted manuscript is the version of the article upon submission and before peer-review. There can be important differences between the submitted version and the official published version of record. People interested in the research are advised to contact the author for the final version of the publication, or visit the DOI to the publisher's website.

- The final author version and the galley proof are versions of the publication after peer review.

- The final published version features the final layout of the paper including the volume, issue and page numbers.

Link to publication

\footnotetext{
General rights rights.

- You may freely distribute the URL identifying the publication in the public portal. please follow below link for the End User Agreement:

www.umlib.nl/taverne-license

Take down policy

If you believe that this document breaches copyright please contact us at:

repository@maastrichtuniversity.nl

providing details and we will investigate your claim.
}

Copyright and moral rights for the publications made accessible in the public portal are retained by the authors and/or other copyright owners and it is a condition of accessing publications that users recognise and abide by the legal requirements associated with these

- Users may download and print one copy of any publication from the public portal for the purpose of private study or research.

- You may not further distribute the material or use it for any profit-making activity or commercial gain

If the publication is distributed under the terms of Article $25 \mathrm{fa}$ of the Dutch Copyright Act, indicated by the "Taverne" license above, 
not in the other groups. The BWV group also had increased vitality and reduced tension and sleep disturbance, although these benefits also followed Mindfulness training. The Mindfulness group was the only group who had an increase in calmness and in a sense of being grounded, and they had a comparatively greater increase in absorption than the other groups. All three groups had improved stress, vitality and mindfulness post-intervention, although none of the groups showed any change in salivary cortisol, attention, memory or health. In conclusion, significant improvements in well-being followed training in all three practices, although BWV was unique in its benefits to depression, tiredness and sleep latency. Further research is needed to investigate its effects, and to isolate which exercises produce them.

doi:10.1016/j.neulet.2011.05.135

A randomised controlled single-blind trial of the efficacy of Reiki in benefitting mood and well-being

Deborah Bowden, Lorna Goddard, John Gruzelier

Goldsmiths, University of London, UK

This is a constructive replication of a previous trial conducted by [2], where students who had received Reiki demonstrated greater health and mood benefits than those who received no Reiki. The current study examined impact on anxiety/depression. 40 university students - half with high depression and/or anxiety and half with low depression and/or anxiety - were randomly assigned to receive Reiki or to a non-Reiki control group. Participants experienced six 30-minute sessions over a period of two to eight weeks, where they were blind to whether non-contact Reiki was administered as their attention was absorbed in a guided relaxation. The efficacy of the intervention was assessed pre-post intervention and at five-week follow-up by self-report measures of mood, illness symptoms and sleep. The participants with high anxiety and/or depression who received Reiki showed a progressive improvement in overall mood, which was significantly better at five-week followup, while no change was seen in the controls. While the Reiki group did not demonstrate the comparatively greater reduction in symptoms of illness seen in our earlier study, the findings of both studies suggest that Reiki may benefit mood.

\section{Reference}

[1] D. Bowden, L. Goddard, J.H. Gruzelier, A randomised controlled single-blind trial of the efficacy of Reiki at benefiting mood and well-being, Evidence-Based Complimentary and Alternative Medicine (2011).

[2] D. Bowden, L. Goddard, J.H. Gruzelier, A randomised controlled single-blind trial of the effects of Reiki and positive imagery on well-being and salivary cortisol, Brain Research Bulletin 81 (2010) 66-72.

doi:10.1016/j.neulet.2011.05.136

\section{Assessing effects of neurofeedback on emotional interference \\ Marinus Breteler, Sjoerd Wijnands Radboud University Nijmegen, Netherlands}

Approach: 40 students received seven NFB sessions of 30 min each. Four conditions were trained, based on SMR neurofeedback at $\mathrm{Cz}$ : visual and auditive feedback (VFAF); visual feedback and auditive placebo (VFAP); visual placebo and auditive feedback (VPAF); visual and auditive placebo (VPAP). An operant response task was administered both before and after NFB sessions. In between presentations of pictures from the International Affective Picture System (IAPS) subjects were to press a keyboard with their left hand when a circle was presented and with their right hand when a square was presented.

Results: SMR and theta increased over time in a repeated measures design, no interaction effects with condition were found. SMR (5.0 and $5.7 \mathrm{uV})$ and theta $(11.1$ and $11.9 \mathrm{uV})$ were not significantly different before and after NFB. In the operant response task, a main effect of time was found for errors in the negativevalence pictures: after NFB the number of correct responses was decreased. A condition-by-time interaction effect was found for reaction time: whereas in the VPAP condition a decrease of reaction time was found with negative-valence pictures, in the VFAF condition the decrease was smaller or the reaction time even increased. No interaction effects were found for errors.

Discussion: In spite of lack of objective support for changes in EEG, neurofeedback appears to have affected emotional interference. The increased response time may be due to a decrease in impulsivity. Another possible explanation may be increased activity of the pulvinar due to NFB, thus enhancing the affective strength of the negative-valence pictures shown. Subjects were not asked for their beliefs about the condition they were in. This leaves room for methodological factors influencing the results.

doi:10.1016/j.neulet.2011.05.137

Enhanced dopamine availability and response readiness. The influence of 3 doses of methylphenidate on contingent negative variation in the EEG of healthy volunteers

Anke Linssen ${ }^{1}$, Eric Vuurman ${ }^{1}$, Anke Sambeth ${ }^{1}$, Stephane Navé ${ }^{2}$, Wim Riedel ${ }^{2}$

${ }^{1}$ Dept. of Neuropsychology \& Psychopharmacology, FPN, Maastricht University, Maastricht, The Netherlands

2 CNS pRED Roche Basel, Basel, Switzerland

The basal ganglia play an important role in motor control, which is dependent on dopaminergic input. Preparation of a motor response has been associated with dopamine release in the basal ganglia and response readiness may therefore serve as a pharmacodynamic marker of dopamine activity. We measured response readiness using the amplitude of the contingent negative variation (CNV), a slow negative shift in the electroencephalogram. The CNV is evoked in a paradigm in which a warning stimulus (S1) signals the occurrence of the imperative stimulus (S2) 4 seconds later, to which the participant has to respond. CNV was assessed in healthy volunteers after administration of placebo or 10,20 or $40 \mathrm{mg}$ of methylphenidate, a catecholamine re-uptake blocker which primarily enhances the synaptic concentration of dopamine and to a lesser extent also noradrenaline. Episodic memory was measured using a word learning test. In addition, participants filled out two visual analog scales measuring subjective ratings of mood and alertness: Profile of Mood States (POMS) and Bond \& Lader (B\&L). Results indicated that methylphenidate dose-dependently increased CNV amplitude and decreased reaction times. Episodic memory performance improved. Furthermore participants reported improved mood, feeling more alert, vigorous and content and less angry and tired after methylphenidate. These results indicate that dopamine availability increases response readiness as measured by the CNV paradigm. The CNV appears to be a good candidate biomarker for assessing changes in dopaminergic function by treatments that either directly or indirectly target the dopaminergic system.

doi:10.1016/j.neulet.2011.05.138 